\title{
RELAÇÃO DA TEMPERATURA DA ÁGUA COM OS NÍVEIS DE PARASITISMO POR Cichlidogyrus spp. (MONOGENEA: ANCYROCEPHALIDAE) EM Oreochromis niloticus
}

\author{
RELATIONSHIP BETWEEN WATER TEMPERATURE AND Cichlidogyrus SPP. \\ (MONOGENEAN: ANCYROCEPHALIDAE) PARASITISMO LEVELS IN \\ Oreochromis niloticus

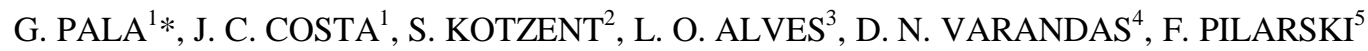

\section{RESUMO}

O objetivo deste estudo foi avaliar a sazonalidade de Cichlidogyrus spp. parasitando as brânquias de tilápias criadas em tanques-rede e correlacionar os níveis de parasitismo com a temperatura da água.

As coletas foram realizadas em duas pisciculturas comerciais, produtoras de tilápia, localizadas no Estado de São Paulo. Uma propriedade situada no Rio Tietê (propriedade 1) e outra no Rio Grande (propriedade 2). Foram coletados mensalmente, 30 peixes de cada uma, no período de setembro de 2013 a agosto de 2014. Após a captura, os animais foram medidos, pesados e mortos por meio de secção da medula espinhal, as brânquias removidas e acondicionadas em formol a 5\% e os monogenóideos quantificados. A temperatura foi aferida no final de cada coleta utilizando cinco pontos previamente demarcados em cada piscicultura, usando sonda YSI 55. O teste não-paramétrico de Kruskal Wallis e o teste de Dunn foram utilizados e os dados analisados no software GraphPad Prism 6, para determinar possíveis diferenças de parasitismo nas estações do ano e coeficiente de correlação de Spearman $r$ foi usado para associar o nível parasitismo com as temperaturas. Nas pisciculturas 1 e 2, os valores mais elevados de temperatura foram obtidos no Verão $\left(29,0^{\circ} \mathrm{C}\right.$ e $\left.29,7^{\circ} \mathrm{C}\right)$ e Outono $\left(25,9^{\circ} \mathrm{C}\right.$ e $\left.26,9^{\circ} \mathrm{C}\right)$, assim como os níveis de parasitismo, diferindo significativamente da Primavera $\left(25,4^{\circ} \mathrm{C}\right.$ e $\left.24,2^{\circ} \mathrm{C}\right)$ e Inverno $\left(21,1^{\circ} \mathrm{C}\right.$ e $\left.22,4^{\circ} \mathrm{C}\right)$, demonstrando correlação positiva entre o parasitismo e a temperatura da água na propriedade $1(r=0,26 ; p<0,001)$ e propriedade $2(r=0,25 ; \mathrm{p}<0,001)$. O estudo da variação parasitária constitui importante ferramenta na avaliação da qualidade do pescado e do meio aquático no qual estão instaladas as pisciculturas, o que permite um planejamento preventivo exato e eficaz do manejo sanitário, evitando gastos desnecessários com o uso inadequado de medicamentos e consequentes surtos de mortalidade causados por infecções bacterianas decorrente da injúria parasitária.

PALAVRAS-CHAVE: PREVENÇÃO. SAZONALIDADE. TANQUES-REDE.

AGRADECIMENTOS: As Pisciculturas pelo suporte e fornecimento dos peixes e a Trouw Nutrition pelo apoio financeiro ao projeto

ÁREA TEMÁTICA: Doenças Parasitárias

\footnotetext{
${ }^{1}$ Pós-graduandas do Centro de Aquicultura da UNESP, Laboratório de Patologia de Organismos Aquáticos, Jaboticabal- SP.*gabi.caunesp@gmail.com.

${ }^{2}$ Pós-graduanda do Programa de Microbiologia Agropecuária, Laboratório de Patologia de Organismos Aquáticos FCAV, Jaboticabal- SP.

${ }^{3}$ Graduando em Zootecnia, Faculdade de Ciências Agrárias e Veterinárias, Jaboticabal-SP.

${ }^{4}$ Zootecnista, Mestre em Aquicultura, Trouw Nutrition, Pitangueiras-SP.

${ }^{5}$ Pesquisadora do Laboratório de Patologia de Organismos Aquáticos do Centro de Aquicultura da UNESP.
} 